\title{
Stage I Merkel Cell Carcinoma AJCC v7
}

National Cancer Institute

\section{Source}

National Cancer Institute. Stage I Merkel Cell Carcinoma A/CC v7. NCI Thesaurus. Code C85889.

Stage I includes: IA: (T1, pN0, M0) and IB: (T1, CNO, M0). T1: Primary tumor equal or less than $2 \mathrm{~cm}$ in size. pN0: No regional lymph node metastasis by pathologic examination. cNO: No regional lymph node metastasis by clinical examination. MO: No distant metastasis. (AJCC 7th Ed.) 